\title{
PENGARUH KOMPETENSI PUSTAKAWAN TERHADAP KUALITAS LAYANAN DI DINAS PERPUSTAKAAN DAN ARSIP KOTA BIMA
}

\author{
Syahruramadhan \\ Universitas Islam Negeri Alauddin Makassar, Sulawesi Selatan, Indonesia \\ syahrulsangaji76@gmail.com \\ Noer Jihad Saleh \\ Universitas Hasanuddin Makassar \\ M. Dahlan M \\ Universitas Islam Negeri Alauddin Makassar
}

\begin{abstract}
Abstrac
This thesis discusses the influence of librarian competence on quality of service at the Department of Library and Archives of Bima City with the intention to: 1) know how the librarian competence at the Department of Library and Archives of Bima City, 2) to know How the service quality at the Department of Library and Archives of Bima City, 3) to know how far the influence of the librarian's competence on the quality of service at the Department of Library and Archives of Bima City. This type of research is quantitative research, which is located at the Department of Library and Archives of Bima City using a managerial approach. A managerial approach is a systematic and orderly approach to drafting and involving integrated elements to see the influence of librarian's competence on the quality of service. The study consisted of one independent variable and one variable, the population in the study was the entire community of Bima who visited the library during the study. The selected sample withdrawal technique is Accidental sampling technique
\end{abstract}


that is done by determining who happens to be encountered by researchers and is considered appropriate to represent a population. The results of the research obtained from the collection of data through observations, polls and documentation processed using SPSS, is known that librarian competence has a significant influence on the quality of service in the Department of Library and Archives of Bima City. Visible from a simple linear regression test result comparing the significance value to the probability value and comparing the Thitung and Ttabel values. Based on the significance value: Known significance value of $0.000<0.05$ so that it can be concluded that variable $X$ affects the variable $Y$. Based on the value T: Known calculated $t$ value of $3.417>T$ table of 2.048 so that it can be concluded that variable $X$ affects against the variable $Y$, with a regression equation value of 0.322 . The regression coefficient is positively valued. The implications of this research are that the training and the development of the librarian are further improved from the institutions that are in the organization of the existing libraries, so that the quality or competence of the librarians is more High appreciation. In addition, it is also hoped for librarians to always uphold the professional code of ethics so that it can maintain the profession and dignity of the librarian.

Keyword: competency of librarian, service quality

\begin{abstract}
Abstrak
Tesis ini membahas tentang Pengaruh Kompetensi Pustakawan terhadap Kualitas Layanan di Dinas Perpustakaan dan Arsip Kota Bima dengan tujuan untuk: 1) Mengetahui Bagaimana Kompetensi Pustakawan di Dinas Perpustakaan dan Arsip Kota Bima, 2) Untuk mengetahui Bagaimana Kualitas Layanan di Dinas Perpustakaan dan Arsip Kota Bima, 3) c. Untuk mengetahui Sejauh Mana Pengaruh Kompetensi Pustakawan Terhadap Kualitas Layanan di Dinas Perpustakaan dan Arsip Kota Bima. Jenis penelitian ini adalah penelitian kuantitatif, yang berlokasi di Dinas Perpustakaan dan Arsip Kota Bima dengan menggunakan pendekatan manajerial. Pendekatan
\end{abstract}


manajerial adalah sebuah pendekatan yang bersifat sistematis dan teratur dalam menyusun dan melibatkan unsur-unsur yang terpadu untuk melihat pengaruh kompetensi pustakawan terhadap kualitas layanan. Penelitian ini terdiri atas satu variabel independen dan satu variabel, populasi dalam penelitian ini adalah seluruh masyarakat Kota Bima yang berkunjung ke perpustakaan selama penelitian berlangsung. Teknik penarikan sampel yang dipilih adalah Accidental sampling yakni teknik yang dilakukan dengan cara menentukan siapa saja yang kebetulan ditemui oleh peneliti dan dipandang tepat untuk mewakili sebuah populasi. Hasil penelitian yang didapat dari pengumpulan data melalui observasi, angket dan dokumentasi yang diolah menggunakan SPSS, diketahui bahwa Kompetensi Pustakawan memiliki pengaruh yang cukup signifikan terhadap Kualitas Layanan di Dinas Perpustakaan dan Arsip Kota Bima. Terlihat dari hasil uji regresi linear sederhana yaitu membandingkan nilai signifikansi dengan nilai probabilitas dan membandingkan nilai thitung dan ttabel. Berdasarkan nilai signifikansi: diketahui nilai signifikansi sebesar $0,000<0,05$ sehingga dapat disimpulkan bahwa variabel $\mathrm{X}$ berpengaruh terhadap variabel $\mathrm{Y}$. Berdasarkan nilai $\mathrm{t}$ : diketahui nilai t hitung sebesar 3,417 > t tabel sebesar 2,048 sehingga dapat disimpulkan bahwa variabel $\mathrm{X}$ berpengaruh terhadap variabel $\mathrm{Y}$, dengan nilai persamaan regresi 0,322 . Koefisien regresi tersebut bernilai positif. Implikasi dari penelitian ini adalah sebaiknya pelatihan dan pengembangan kepustakawanan lebih ditingkatkan lagi dari lembaga-lembaga yang membawahi setiap organisasi perpustakaan yang ada, sehingga kualitas atau kompetensi seorang pustakawan lebih di apresiasi tinggi. Selain itu diharapkan juga bagi pustakawan untuk selalu memegang teguh kode etik profesi sehingga dapat menjaga harkat dan martabat profesi pustakawan.

Kata Kunci: Kompetensi Pustakawan, Kualitas Layanan 


\section{A. Pendahuluan}

Pustakawan merupakan salah satu sumber daya yang menggerakkan sumber daya lain dalam organisasi perpustakaan yang memungkinkan perpustakaan dapat berperan secara optimal dalam melaksanakan tugas pokok dan fungsinya, sehigga pustakawan menjadi ujung tombak keberhasilan dalam penyebarluasan informasi di perpustakaan. Dalam UU No. 43 Tahun 2007 juga ditegaskan bahwa pustakawan adalah seorang yang memiliki kompetensi yang diperoleh melalui pendidikan dan atau pelatihan kepustakawanan serta mempunyai tugas dan tanggung jawab untuk melaksanaan pengelolaan dan pelayanan perpustakaan.

Menjadi pustakawan yang ideal adalah tuntutan jika kita ingin dikatakan sebagai seorang yang profesional dan tentunya yang sesuai dengan standar profesi itu sendiri. Namun terkadang di lapangan banyak dijumpai para pustakawan masih belum menunjukan sikap dan kompetensi yang memadai. Dimana pengetahuan, sikap dan keterampilan masih jauh dari harapan sebagai pustakawan yang ideal.

Membangun pustakawan yang ideal bisa kita ibaratkan seperti akan membangun sebuah rumah. Maka, yang pertama adalah kita bangun pondasi yang kokoh yaitu dengan jenjang pendidikan yang jelas, tiang-tiang dan tembok yang kuat yaitu mengasah pengetahuan dasar yang di dapat dari proses pendidikan format baik lewat pengembangan diri pribadi maupun mengikuti proses pelatihan dan terakhir adalah menambahkan atap sebagai pelangkap dari seluruh proses pembangunan yaitu dengan menunjukkan karya-karya dari hasil proses pendidikan formal dan pengembangan non formal. ${ }^{1}$

Pustakawan yang profesional adalah pustakawan yang mampu menguasai seluruh aspek pekerjaan yang ada pada unit-unit

1 Sulistyo Basuki. Pengantar Ilmu Perpustakaan (Jakarta:Gramedia Pustaka, 1993) h. 25 
bidang perpustakaan, dokumentasi dan informasi. Namun kondisi ini masih jarang dijumpai khusunya di perpustakaan-perpustakaan daerah, karena masih banyaknya dijumpai posisi yang harusnya di tempati oleh tenaga ahli perpustakaan di tempati oleh orangorang yang beground pendidikanya bukan dari perpustakaan itu sendiri. Persoalan semacam ini menjadi keresahan dan kegelisahan yang kian menggerogoti ketenangan para alumni jurusan Ilmu Perpustakaan saat ini yang belum juga mendapatkan jawaban yang pasti atas persoalan ini baik secara personal maupun dengan regulasi yang tepat.

Sesuai dengan Standar Nasional Perpustakaan (SNP) Perpustakaan Nasional RI tahun 2011 tentang kualifikasi tenaga pengelola perpustakaan daerah adalah orang yang lulusan minimal Starata Satu (S1) di bidang ilmu perpustakaan dan informasi, terlibat aktif dalam organisasi perpustakaan dibuktikan dengan kartu anggota atau sertifikat. Perpustakaan di kelola minimal 2 orang pustakawan untuk 500 anggota perpustakaan 1 orang pustakawan dan 1 orang staff, atau dengan perbandingan 1 banding 250 .

Ditambah lagi berkembang fenomena baru akhir-akhir ini yaitu pustakawan tidak hanya bertugas sebatas menyusun dan mendata buku. Namun lebih dari itu bahwa pustakawan juga harus mampu menciptakan suasana senyaman mungkin baik dari segi fasilitas, koleksi maupun pelayanan.

Untuk mencapai cita-cita yang demikian pustakawan dituntut harus memiliki kemampuan yang lebih serta mampu menyesuaikan diri dengan situasi dan kondisi masyarakat pengguna. Pustakawan harus mampu memperlakukan pengunjung dan khususnya anggota perpustakaan sebagai aset penting perpustakaan untuk meningkatkan kemajuan perpustakaan.

User needed diperlukan untuk membuat gerakan semakin solid dan komitmen bersama untuk mengelola perpuustakaan secara kreatif dan inovatif dengan tetap mengedepankan kebersamaan. Pustakawan juga harus kreatif mengembangkan berbagai aktivitas dan kreativitas baru demi mengembangkan perpustakaan. 
Untuk menunjang perpustakaan yang profesional membutuhkan pustakawan yang profesional pula yang memiliki sumber daya manusia yang mapan serta memiliki sosial skils agar mampu mengembangkan perpustakaan yang berbasis pada pelayanan dan perpustakaan yang ideal.

Pustakawan merupakan ujung tombak bagi keberhasilan suatu perpustakaan dalam meningkatkan minat baca masyarakat. Tetapi profesi ini ternyata belum memperoleh perhatian yang layak dari pemerintah (terutama pemerintah daerah). Pada setiap rekrutmen CPNS, jarang sekali pemerintah daerah di Indonesia yang mengajukan formasi CPNS untuk jabatan fungsional pustakawan untuk para lulusan Sarjana dan Diploma III Perpustakaan. Padahal hingga saat ini jumlah pustakawan di kabupaten/kota di Indonesia masih sangat sedikit.

Selain itu salah satu kendala utama dalam pengembangan perpustakaan di tanah air adalah masih minimnya jumlah pustakawan. Cukup banyak perpustakaan sekolah yang belum memiliki tenaga pustakawan.

Pemerintah perlu menyelesaikan masalah ini dengan mengangkat pustakawan kontrak. Kalau untuk memenuhi kekurangan tenaga pengajar pemerintah mengangkat guru kontrak, apa salahnya jika sekarang pemerintah mengangkat pustakawan kontrak. Karena kebutuhan dunia pendidikan terhadap tenaga pengajar hakekatnya sama pentingnya dengan kebutuhan perpustakaan terhadap pustakawan. Kendati demikian pemerintah juga selain dari fokus penambahan jumlah juga harus memperhatikan kualitas pustakawan yang dapat dilihat dari mampu dan tidaknya dia menjalankan tugas pokok dan fungsinya dengan baik.

Keputusan Menpan Nomor 33 Tahun 1998 menyebutkan bahwa tugas pokok pustakawan meliputi Pengorganisasian dan pendayagunaan koleksi bahan pustaka/sumber informasi, pemasyarakatan perpustakaan, informasi dan dokumentasi serta pengkajian pengembangan perpustakaan. Dalam SK Menpan 
tersebut membagi dua jenis pekerjaan pustakawan yaitu: tenaga teknis dan tenaga analisisi. Pekerjaan kepustakawanan yang bersifat teknis adalah jenis kegiatan kepustakawanan yang membutuhkan lebih banyak kemampuan hastawi (Keterampilan) dari pada kemampuan intelektual (Daya piker) di pihak lain pekerjaan kepustakawanan yang membutuhkan kemampuan intelektual yang baik. Di pihak lain, pekerjaan kepustakawanan yang membutuhkan lebih banyak kemampuan intelektua (Daya Pikir) dari pada membutuhkan lebih banyak kemampuan hastawi (keterampilan). ${ }^{2}$

Sejalan dengan dua konsep pekerjaan pustakawan tersebut, jabatan pustakawan juga digolongkan atas dua kelompok yaitu Pustakawan dan Asisten Pustakawan. Dengan demikian, dapat diartikan bahwa Pustakawan lebih pada pekerjaanya sebagai tenaga ahli sementara asisten pustakawan pekerjaanya lebih pada sesuatu yang bersifat keterampilan atau teknis. Namun pada jenjang tertentu asisten pustakawan juga akan bisa menjadi pustakawan dengan cara mengembangkan diri dan keahlian. Untuk meniti jenjang karir, pustakawan perlu menunjukkan produktifitas yang dapat dikonversikan dalam bentuk ukuran yaitu angka kredit.

Tugas pokok pustakawan sebagaimana disebutkan diatas yaitu pustakawan meliputi Pengorganisasian dan pendayagunaan koleksi bahan pustaka/sumber informasi, pemasyarakatan perpustakaan, informasi dan dokumentasi serta pengkajian pengembangan perpustakaan. Maka ruang lingkup kerja pustakawan dan professional informasi terkait adalah mengumpulkan dan menyimpan bahan pustaka serta mencari dan memberikan informasi sesuai dengan kebutuhan masyarakat pengguna ${ }^{3}$

Melihat perspektif yang diuraikan di atas, Pustakawan Indonesia selayaknya dapat menempatkan dirinya dalam situasi nyata. Perkembangan teknologi informasi, nampaknya menjanjikan kecerahan kerja pustakawan. Dengan berkembangnya teknologi

${ }^{2}$ Blasius Sudarsono, Antologi Kepustakawanan Indonesia, (Jakarta: Ikatan Pustakawan Indonesia, 2006) h. 416

${ }^{3}$ Blasius Sudarsono, Antologi Kepustakawanan Indonesia, (Jakarta: Ikatan Pustakawan Indonesia, 2006) h. 419 
informasi juga berpengaruh terhadap berkembangnya tugas dan fungsi pustakawan.

Fungsi pustakawan adalah sebagai pelayan pendayagunaan koleksi perpustakaan. Pelayan pendayagunaan koleksi perpustakaan merupakan jenis layanan perpustakaan yang mengolah informasi menjadi informasi yang siap pakai. Koleksi harus diberi ciri atau kode agar dikenali sebagai hak milik suatu perpustakaan. Kode bisa berupa cap atau tanda gambar tertentu yang menunjukkan hak kepemilikan. Selain itu, koleksi perlu diatur penempatannya pada rak agar tertata dan tersusun sesuai dengan pembagian kelompok bidang ilmu pengetahuan yang sedang berkembang. Informasi dari koleksi yang dimiliki suatu perpustakaan dapat digunakan sesuai kebutuhan pemustaka peprustakaan. Hal ini sehubungan dengan layanan yang diberikan kepada pemustaka agar informasi yang dibutuhkan siap pakai.

Dalam layanan pendayagunaan koleksi, peran pemustaka merupakan aset penting dalam penyelengaraan perpustakaan. Berkembang tidaknya suatu perpustakaan tergantung dari jenis layanan yang diinginkan pemustaka. Pustakawan dan cara bekerjanya dalam melayani pemustakanya, dituntut untuk berkompeten, familiar dan bertanggung jawab dalam penggunaan dan penyimpanan sumber-sumber informasi, metode telekomunikasi, dan kemampuan komunikasi interpersonal.

Kompetensi menjadi salah satu faktor penting yang harus dimiliki setiap individu dalam melaksanakan pekerjaan, hal ini berlaku juga untuk pustakawan. Pustakawan ialah seseorang yang memiliki kompetensi kepustakawanan yang diperoleh melalui pendidikan maupun pelatihan kepustakawanan yang memiliki tugas utama mengelola perpustakaan dan melayani pemustaka sebagaimana yang dijelaskan dalam UU No. 43 tahun 2007 Pasal 1 Ayat 8 tentang Perpustakaan. Hal tersebut menunjukkan tidak semua yang bekerja di perpustakaan dapat dikatakan sebagai 
pustakawan, pustakawan haruslah memiliki kompetensi yang diperoleh dari pendidikan maupun pelatihan kepustakawanan ${ }^{4}$

Berdasarkan latar belakang masalah tersebut maka ruang lingkup penelitian ini adalah pengaruh kompetensi pustakawan terhadap kualitas layanan di Kantor Arsip dan Perpustakaan Kota Bima

Tujuan dari penelitian ini adalah untuk mengetahui bagaimana kompetensi pustakawan di dinas perpustakaan dan arsip Kota Bima, untuk mengetahui bagaimana kualitas layanan di dinas perpustakaan dan arsip Kota Bima dan untuk mengetahui sejauh mana pengaruh kompetensi pustakawan terhadap kualitas layanan di dinas perpustakaan dan arsip Kota Bima.

Penelitian ini adalah penelitian hubungan atau pengaruh (penelitian asosiatif), dengan menggunakan pendekatan kuantitatif. Dalam penelitian ini, peneliti menggunakan jenis penelitian statistik deskriptif dengan pendekatan kuantitatif. Jenis penelitian statistik deskriptif adalah merupakan jenis penelitian yang berfungsi untuk mendeskripsikan atau memberi gambaran terhadap obyek yang diteliti melalui data sampel atau populasi sebagaimana adanya. ${ }^{5}$

Pendekatan penelitian yang digunakan dalam penelitian ini adalah pendekatan Manajerial atau lebih umum dikenal dengan istilah pendekatan manajemen. Pendekatan manajerial adalah sebuah pendekatan yang bersifat sistematis dan teratur dalam menyusun dan melibatkan unsur-unsur yang terpadu untuk melihat pengaruh kompetensi pustakawan terhadap kualitas layanan.

${ }^{4}$ Lucky Dewi Pamungkas. Dkk: Pengaruh Kompetensi Pustakawan Terhadap Prestasi Kerja (Studi pada Perpustakaan Universitas Brawijaya), (Vol. 3, No. 5) h. 739

${ }^{5}$ Sugiyono, Metode Penelitian Kuantitatif, Kualitatif dan $R$ \& $D$. (Bandung: Alfabeta: 2008) h. 21 


\section{B. Pembahasan}

\section{Kompetensi Pustakawan di Dinas Perpustakaan dan Arsip Kota Bima}

Kompetensi menjadi salah satu faktor penting yang harus dimiliki setiap individu dalam melaksanakan pekerjaan, hal ini berlaku juga untuk pustakawan. Pustakawan ialah seseorang yang memiliki kompetensi kepustakawanan yang diperoleh melalui pendidikan maupun pelatihan kepustakawanan yang memiliki tugas utama mengelola perpustakaan dan melayani pemustaka (UU No. 43 tahun 2007 Pasal 1 Ayat 8 tentang Perpustakaan). Hal tersebut menunjukkan tidak semua yang bekerja di perpustakaan dapat dikatakan sebagai pustakawan, pustakawan haruslah memiliki kompetensi yang diperoleh dari pendidikan maupun pelatihan kepustakawanan.

Kompetensi pustakawan dapat dilihat dari pengetahuan pustakawan dalam mengelola informasi, ketrampilan interpersonal, dan sikap profesional yang ditunjukkan pustakawan dalam mengelola perpustakaan. Kompetensi pustakawan harus terus ditingkatkan menginggat tugas pustakawan dari waktu ke waktu yang tidak mudah. Selain itu, tuntutan peningkatan kompetensi menjadi hal yang wajar agar pustakawan menghasilkan prestasi kerja yang baik. ${ }^{6}$

Dinas Perpustakaan dan Arsip Kota Bima merupakan perpustakaan yang berorientasi pada kebutuhan masyarakat yang ada di wilayah pemerintahan Kota Bima baik kelompok anak-anak, remaja, dewasa maupun tua. Perpustakaan ini memiliki 1 orang yang masuk dalam kategori kelompok fungsional atau pustakawan yang bertindak sebagai koordinator dan di bagian layanan terdapat 4 orang pegawai.

Pustakawan yang memiliki kompetensi atau kemampuan memiliki pengaruh yang cukup penting dalam memberikan

${ }^{6}$ Wicaksono. Kompetensi Perpustakaan dan Pustakawan dalam Implementasi Teknologi Informasi di Perpustakaan (Jakarta: Rajawali Pers, 2004) h. 14-16 
layanan yang berkualitas kepada pengguna perpustakaan. Pustakawan yang memiliki kompetensi atau kemampuan dapat dilihat dari kualifikasi pendidikan baik formal maupun nonformal dan kematangan keterampilan sosial yang dimiliki.

Selain dari kriteria tersebut pustakawan yang memiliki kompetensi atau keterampilan sosial dapat dilihat dari pengembangan indikator gambaran kompetensi pustakawan dengan langkah penebaran angket kepada responden. Butir pernyataan yang terdapat dalam angket sebagai gambaran kompetensi atau keterampilan sosial pustakawan secara umum terdiri dari: 1) Memiliki ilmu pengetahuan, keterampilan, kecakapan komunikasi dan keahlian yang mumpuni dalam bidangnya, 2) Memiliki tingkat kemandirian yang tinggi, 3) Memiliki kemampuan kerjasama yang baik, 4) Berorientasi pada pelayanan dan menjunjung tinggi kode etik, 5) Berorientasi pada pengembangan perpustakaan.

Hasil dari jawaban 30 responden untuk semua pernyataan tentang kompetensi pustakawan Dinas Perpustakaan dan Arsip Kota Bima yang berjumlah 13 butir. Responden yang menjawab sangat tidak setuju dengan nilai total 2, yang menjawab tidak setuju dengan nilai total 53, yang menjawab setuju dengan nilai total 198 dan yang menjawab sangat setuju dengan nilai total 124. Jadi total keseluruhan jawaban responden mendapat skor 1237 dengan bobot 41,18 .

Dari uraian distribusi frekuensi jawaban responden di atas menunjukkan bahwa Kompetensi Pustakawan Dinas Perpustakaan dan Arsip Kota Bima adalah baik.

\section{Kualitas Layanan di Dinas Perpustakaan dan Arsip Kota Bima}

Layanan adalah setiap tindakan atau kegiatan yang dapat ditawarkan oelh suatu pihak kepada pihak lain. Layanan merupakan perilaku produsen dalam rangka memenuhi kebutuhan dan keinginan konsumen demi tercapainya kepuasan pada konsumen. Dengan demikian, jika pada kenyataanya pelayanan yang diberikan 
melebihi dari apa yang diharapkan oleh para pemustaka, mereka akan merasa sangat puas. Namun, jika pelayanan yang diberikan perpustakaan sama dengan yang diharapkan mereka akan puas. Sebaliknya, jika layanan diberikan tidak sesuai atau bahkan di bawah harapanya, maka mereka akan merasa tidak puas atau bahkan sangat tidak puas. ${ }^{7}$

Sumber daya manusia (SDM) yang memadai atau dengan persentase cukup baik diharapkan akan bermuara pada pelayanan yang memiliki kualitas yang cukup baik pula. Secara umum layanan yang harus diberikan pada pemustaka adalah: (1) Akurasi layanan, (2) Kesopanan dan keramahan dalam memberikan layanan, (3) Kelengkapan, (4) Kemudahan mendapatkan layanan, dan (5) Kenyamanan dalam memperoleh layanan.

Dalam penelitian ini, peneliti memberikan pernyataan sebanyak 13 butir dalam bentuk angket kepada responden tentang kualitas layanan di Dinas Perpustakaan dan Arsip Kota Bima.

Jawaban 30 responden untuk semua pernyataan tentang kualitas layanan di Dinas Perpustakaan dan Arsip Kota Bima yang berjumlah 13 butir. Responden yang menjawab sangat tidak setuju dengan nilai total 14, yang menjawab tidak setuju dengan nilai total 79 , yang menjawab setuju dengan nilai total 204 dan yang menjawab sangat setuju dengan nilai total 94. Jadi total keseluruhan jawaban responden mendapat skor 1156 dengan bobot 38,49. Dari uraian distribusi frekuensi jawaban responden di atas menunjukkan bahwa Kualitas Layanan di Dinas Perpustakaan dan Arsip Kota Bima adalah baik.

\section{Pengaruh Kompetensi Pustakawan terhadap Kualitas Layanan di Dinas Perpustakaan dan Arsip Kota Bima}

Untuk melihat pengaruh kompetensi pustakawan terhadap kualitas layanan di Dinas Perpustakaan dan Arsip Kota Bima, maka peneliti menggunakan metode Entered/Removed

${ }^{7}$ Kolter, Philip. Manajemen Pemasaran di Indonesia: Analisis, Perencanaan, Implementasi dan Pengendalian, (Jakarta: Salemba Empat, 2002) h. 83 
untuk menganalisis data yang sudah dikumpulkan. Teknik atau metode tersebut digunakan untuk mengetahui dan membuktikan hipotesis pengaruh antara kedua variabel yaitu pengaruh variabel independen (kompetensi pustakawan) terhadap variabel dependen (kualitas layanan).

Dari hasil uji dan alanilis data didapatkan persamaan regresi yang dihasilkan dapat diterjemahkan bahwa konstanta sebesar 25,277 mengandung arti bahwa nilai konsisten variabel Kualitas Layanan adalah sebesar 25,277 dan koefisien regresi X sebesar 0,322 menyatakan bahwa setiap penambahan $1 \%$ nilai Kompetensi Pustakawan, maka nilai kualitas layanan bertambah sebesar 0,322. Koefisien regresi tersebut bernilai positif.

Dari hasil analisis data yang dilakukan menggunakan bantuan aplikasi SPSS24 tersebut dapat disimpulkan bahwa Kompetensi Pustakawan (variabel $\mathrm{X}$ ) berpengaruh terhadap Kualitas Layanan (variabel Y) dengan koefisien regresi bernilai positif. Hasil tersebut didapat berdasarkan dasar pengambilan keputusan Uji Regresi Linear Sederhana. Membandingkan nilai signifikansi dengan nilai probabilitas dan membandingkan nilai thitung dan ttabel yaitu sebagai berikut:

Berdasarkan nilai signifikansi: Dari tabel Coefficients diketahui nilai signifikansi sebesar 0,000 $<0,05$ (nilai probabilitas) sehingga dapat disimpulkan bahwa variabel $\mathrm{X}$ berpengaruh terhadap variabel Y.

Berdasarkan nilai t: Dari tabel Coefficients diketahui nilai t hitung sebesar 3,417 > t tabel sebesar 2,048 sehingga dapat disimpulkan bahwa variabel $\mathrm{X}$ berpengaruh terhadap variabel $\mathrm{Y}$, dengan nilai persamaan regresi 0,322 . Koefisien regresi tersebut bernilai positif.

\section{Kesimpulan}

Kompetensi pustakawan di Dinas Perpustakaan dan Arsip Kota Bima secara persentase dapat dikategorikan baik dengan meninjau gambaran kompetensi atau keterampilan 
sosial pustakawan secara umum yang dibagi dalam beberapa poin berikut ini: 1) Memiliki ilmu pengetahuan, keterampilan, kecakapan komunikasi dan keahlian yang mumpuni dalam bidangnya, 2) Memiliki tingkat kemandirian yang tinggi, 3) Memiliki kemampuan kerjasama yang baik, 4) Berorientasi pada pelayanan dan menjunjung tinggi kode etik, 5) Berorientasi pada pengembangan perpustakaan. Semua item tersebut mendapat respon pernyataan positif dari responden.

Kualitas Layanan di Dinas Perpustakaan dan Arsip Kota Bima secara persentase juga dapat dikategorikan baik dengan meninjau model dan jenis layanan yang haru dipenuhi oleh pustakawan dalam memberikan layanan kepada pemustaka yang secara umum dibagi menjadi lima poin sebagai berikut: (1) Akurasi layanan, (2) Kesopanan dan keramahan dalam memberikan layanan, (3) Kelengkapan, (4) Kemudahan mendapatkan layanan, dan (5) Kenyamanan dalam memperoleh layanan. Dari kelima poin tersebut lebih lanjut dibagi menjadi 13 butir pernyataan dalam angket penelitian dan semuanya hamper mendapatkan tanggapan positif dari resonden sehingga menunjukkan bahwa kualitas layanan di Dinas Perpustakaan dan Arsip Kota itu baik.

Kompetensi Pustakawan (variabel X) berpengaruh terhadap Kualitas Layanan (variabel Y) dengan koefisien regresi bernilai positif. Hasil tersebut didapat berdasarkan dasar pengambilan keputusan Uji Regresi Linear Sederhana. Membandingkan nilai signifikansi dengan nilai probabilitas dan membandingkan nilai thitung dan tabel

Berdasarkan nilai signifikansi: Dari tabel Coefficients diketahui nilai signifikansi sebesar 0,000 $<0,05$ (nilai probabilitas) sehingga dapat disimpulkan bahwa variabel $\mathrm{X}$ berpengaruh terhadap variabel Y.

Berdasarkan nilai t: Dari tabel Coefficients diketahui nilai t hitung sebesar 3,417 > t tabel sebesar 2,048 sehingga dapat disimpulkan bahwa variabel $\mathrm{X}$ berpengaruh terhadap variabel $\mathrm{Y}$, 
dengan nilai persamaan regresi 0,322 . Koefisien regresi tersebut bernilai positif.

Harapan dari peneliti sebaiknya pelatihan dan pengembangan kepustakawanan lebih ditingkatkan lagi dari lembaga-lembaga yang membawahi setiap organisasi perpustakaan yang ada, sehingga kualitas atau kompetensi seorang pustakawan lebih di apresiasi tinggi. Selain itu diharapkan juga bagi pustakawan untuk selalu memegang teguh kode etik profesi sehingga dapat menjaga harkat dan martabat profesi pustakawan.

\section{DAFTAR PUSTAKA}

Blasius Sudarsono, (2006) Antologi Kepustakawanan Indonesia, (Jakarta: Ikatan Pustakawan Indonesia)

Kolter, Philip, (2002) Manajemen Pemasaran di Indonesia: Analisis, Perencanaan, Implementasi dan Pengendalian, (Jakarta: Salemba Empat)

Lucky Dewi Pamungkas. Dkk: Pengaruh Kompetensi Pustakawan Terhadap Prestasi Kerja (Studi pada Perpustakaan Universitas Brawijaya), (Vol. 3, No. 5)

Sugiono (2012) Memahami Penelitian Kualitatif (Cet II; Bandung: PT. Remaja Rosda karya)

Sulistyo Basuki, (1993). Pengantar Ilmu Perpustakaan (Jakarta: Gramedia Pustaka).

Wicaksono. (2004) Kompetensi Perpustakaan dan Pustakawan dalam Implementasi Teknologi Informasi di Perpustakaan (Jakarta: Rajawali Pers) 
